\title{
Assessment of the Evolution and Socio-Economic Impacts of Extreme Rainfall Events in October 2019 over the East Africa
}

\author{
Ladislaus Benedict Chang'a, Agnes Lawrence Kijazi, Kantamla Biseke Mafuru, \\ Alfred Lawrence Kondowe, Sarah Emirald Osima, Habiba Ismail Mtongori, \\ Hashim Karim Ng'ongolo, Omari Hamisi Juma, Edward Michael
}

Tanzania Meteorological Authority, Dar es Salaam, Tanzania

Email: changa60@hotmail.com

How to cite this paper: Chang'a, L.B., Kijazi, A.L., Mafuru, K.B., Kondowe, A.L., Osima, S.E., Mtongori, H.I., Ng'ongolo, H.K., Juma, O.H. and Michael, E. (2020) Assessment of the Evolution and Socio-Economic Impacts of Extreme Rainfall Events in October 2019 over the East Africa. Atmospheric and Climate Sciences, 10, 319-338.

https://doi.org/10.4236/acs.2020.103018

Received: April 9, 2020

Accepted: May 28, 2020

Published: June 1, 2020

Copyright $\odot 2020$ by author(s) and Scientific Research Publishing Inc. This work is licensed under the Creative Commons Attribution International License (CC BY 4.0).

http://creativecommons.org/licenses/by/4.0/

\section{(c) (i) Open Access}

\begin{abstract}
This study aimed at establishing and quantifying the evolution and socio-economic impacts of extreme rainfall events in October 2019. The study also focused on ascertaining the extent to which the Indian Ocean Dipole (IOD) and the El Niño Southern Oscillation (ENSO) influenced anomalous rainfall over East Africa (EA) in October 2019. It employed Singular Value Decomposition (SVD) methods to analyze inter-annual variability of EA rainfall and the Sea Surface Temperature Anomalies (SSTA) over the Indian and Pacific Ocean with a focus on October to December 2019 rainfall season. The SVD analysis enabled the exploration of the leading modes from the mean monthly rainfall and SSTs leading to the determination of the likely influence of the IOD and ENSO respectively. The first SVD coupled modes, which dominate the co-variability between the October rainfall over the EA domain, and SSTA over the Indian and Pacific Oceans based on 1981 to 2010 climatology indicate the monopole positive co-variability with rainfall over the entire EA domain. The corresponding spatial pattern for the SSTA over the Indian Ocean (IO) recaptures the positive IOD event while the central equatorial Pacific Ocean (i.e., over Niño 3.4 region) reveals a monopole positive loading, a typical signal for the warm phase of ENSO. The positive rainfall anomaly over the EA during October is found to be associated with either the IOD event or ENSO condition events independently or in phase. However, the inter-annual variability between October rainfall over EA and ENSO reveals a moderate relationship $(\mathrm{r}=0.4212)$ while a robust association $(\mathrm{r}=$ 0.7084 ) is revealed with IOD. Comparatively, the October 2019 rainfall anomaly peaks the highest in history over the EA and was found to be coupled with highest positive IOD event in record. Unlikely, the 1997 October rainfall
\end{abstract}


(which peaked the second in history), was associated with the co-occurrence of the positive phase of ENSO and IOD events. The findings of this study suggest that the positive IOD coupled mode had large impact on the distribution and variability of the October 2019 rainfall over the EA region.

\section{Keywords}

Indian Ocean Dipole (IOD), ENSO, Sea Surface Temperature, Extreme Events, OND

\section{Introduction}

The livelihood and socio-economic development of majority of the people in East African countries including Tanzania, Kenya, Uganda, Burundi and Rwanda largely depend on rain-fed agricultural activities. The production and productivity in agricultural and other socio-economic activities are largely influenced by the distribution of rainfall and associated variability [1]. The region is often affected by incidences of climate and weather extremes and is among the most flood-prone countries in Africa [2].

The study of East African rainfall, particularly the nature and extent of its variability has received considerable attention and is well documented [3]-[12]. There are multiple factors responsible for modulating rainfall distribution in the region; these include the Inter-Tropical Convergence Zone (ITCZ), the Sea Surface Temperature (SST) over the global Oceans (i.e., the El Niño southern oscillation, ENSO and the Indian Ocean Dipole, IOD mode), and Tropical cyclones among others. These large-scale drivers for the inter-annual East African rainfall variability are well described by a number of researchers [9] [13] [14] [15] [16].

In some parts of the region including Kenya and northern Tanzania, the variability of short rains (i.e., OND) is strongly modulated by the Indian Ocean Dipole mode [17]. A study by [18] indicates a close linkage between the east-west Sea Surface Temperature Anomaly (SSTA) gradients in the tropical Indian Ocean (IO) and the anomalous zonal circulation, which enhances convection over the western IO and northern Tanzania in general. Thus, IOD is one of the powerful modulators of the IO climate, which renders both the normally warm and wet or cooler and drier conditions of the western Indian Ocean (WIO). In its positive phase, IOD drives the IO climate to render wetter than normal conditions at the equatorial WIO [19]. During the negative phase of IOD the drivers of the IO climate are in opposite direction, rendering the drier than normal climate over the equatorial western India Ocean and East Africa (i.e., mainly over Kenya and northern Tanzania).

Over the recent years, the East African region like many other regions has experienced an increasing frequency and intensity of extreme events including heavy precipitation and droughts [20]-[28] which have caused devastating so- 
cio-economic impacts. Climatologically most of the heavy precipitation events have been observed during long rain season (i.e., March to May, MAM). However, in recent years the region has also experienced increasing incidences of disastrous impacts of heavy precipitation during October to December (OND) season [6] with the most striking event occurring during the 2019 OND rainfall season. Several incidences of heavy precipitation and devastating socio-economic impacts including loss of life and destruction of infrastructure have been reported in October 2019 across much of the region. However, details about the extremes including their causes and evolution and the associated quantifiable impacts are lacking.

This study aims at assessing the cause of the October 2019 extreme rainfall events and providing the ranks of these events in historical climatological records and a quantifiable assessment of the associated socio-economic impacts over the Eastern Africa. Much more attention is dedicated to the role of SST over the equatorial IO on rainfall variation.

\section{Data and Methodology}

\subsection{Study Area}

The EA region comprises six countries namely Tanzania, Kenya, Uganda, Burundi, Rwanda and South Sudan. However, the focus of this study is on Tanzania, Kenya and Uganda, located within the $5^{\circ} \mathrm{N}$ and $12^{\circ} \mathrm{S}$ and $29^{\circ} \mathrm{E}$ and $42^{\circ} \mathrm{E}$ (Figure 1). The region is characterized by diverse climate patterns due to complex topographical features. These include the Great Rift Valley, highest mountain in Africa, Mount Kilimanjaro about $5895 \mathrm{~m}$ above sea level, Mount Kenya (5199 m), Mount Rwenzori (5109 m), Mount Elgon (4222 m) and Mount Meru

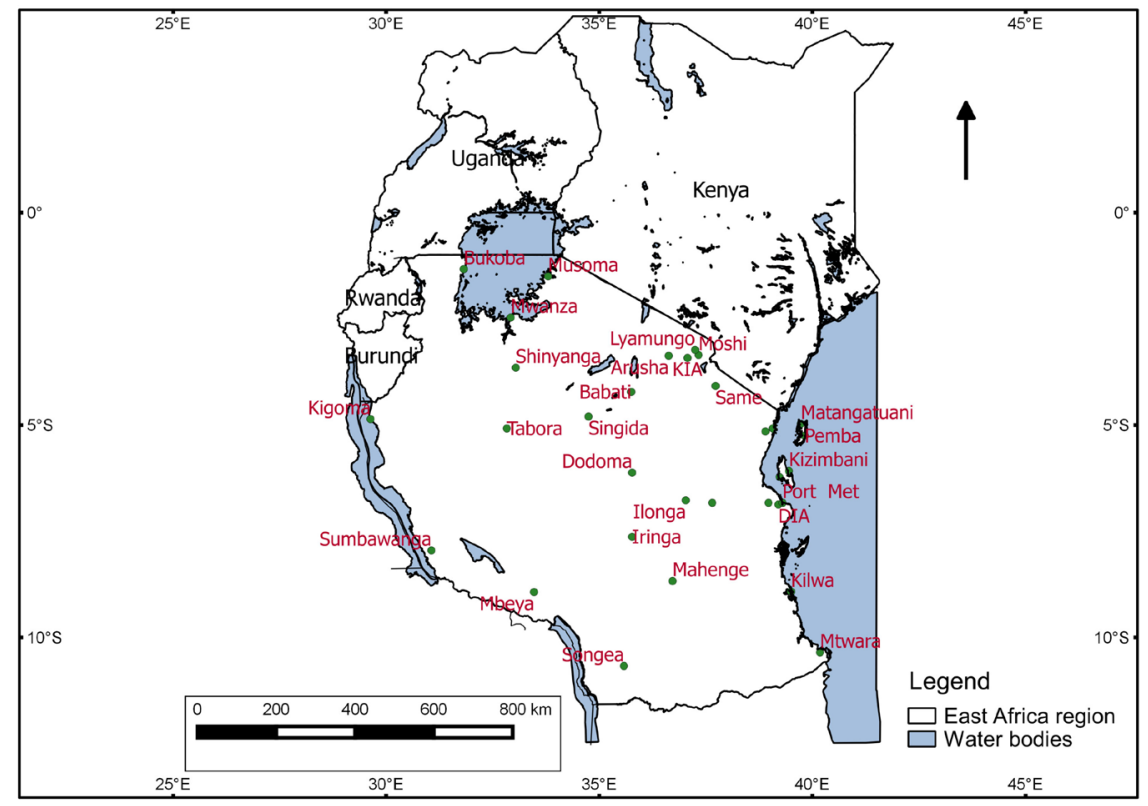

Figure 1. The map showing geographical location of the East Africa (EA) and stations used in the study. 
$(4565 \mathrm{~m})$. The region is also endowed with the presenceof abundant and varying size of water bodies including the Lake Victoria basin $\left(69,485 \mathrm{~km}^{2}\right)$ Lake Tanganyika $\left(32,900 \mathrm{~km}^{2}\right)$, Lake Nyasa $\left(29,600 \mathrm{~km}^{2}\right)$, Lake Albert $\left(5594 \mathrm{~km}^{2}\right)$, Lake Turkana $\left(6405 \mathrm{~km}^{2}\right)$ and Lake Edward $\left(2325 \mathrm{~km}^{2}\right)$. The climate pattern of the region and particularly its rainfall distribution is therefore typified by stronger spatial and temporal variations, which is also amplified by significant differences in relief and vegetation cover. The large areas within the region (including the northern parts of Tanzania and southern parts of Kenya and Uganda) receive bimodal rainfall pattern with "long rains" season in MAM and the "short rains" season in OND associated with the North-South seasonal movement of the main rain belt, the ITCZ [29]. The onset and cessation of rainfall in East Africa is also characterized by stronger variability and is largely influenced by the migratory pattern of the ITCZ. The ITCZ usually migrates southwards through Tanzania during OND, reaching the Southern parts of Tanzania in January and February and returning northwards during MAM. The south-western highlands (SWH), southern region (i.e., Songea), southern coastal areas, western and central parts of the country experience Uni-modal rainfall patterns that normally starts from November and ends in April. In Uganda, the "short rains" season starts a month earlier; running from September to October [29] while some areas around the Lake Victoria basin and eastern regions of the Rift Valley experience trimodal rainfall regime that peaks in June to July (JJA).

\subsection{Data Sets}

This study utilized the daily and monthly rain gauge data sets from twenty-one (21) selected synoptic stations scattered over Tanzania (Figure 1). The stations selection was to include all the bimodal stations since during OND season the region experiences a noticeable impact of the short rain in comparison to unimodal areas where the rain normally starts in November and ends in April. Following the complexity in obtaining the daily and monthly rain gauge data sets from the rest of the East African countries (e.g., Kenya and Uganda), the study made use of the monthly global precipitation climatology center (GPCC) with a $0.5^{\circ} \times 0.5^{\circ}$ grid resolution [30] and climate hazards group infrared precipitation with station data (CHIRPS) with a $2.5^{\circ} \times 2.5^{\circ}$ grid resolution [31]. The gridded rainfall data sets were used to study the monthly (i.e., October, November and December) and seasonal (i.e., OND) climatological rainfall distribution over the Eastern Africa. Meanwhile, the study made use of the monthly SST data sets from the National Oceanic and Atmospheric Administration (NOAA) with $2^{\circ} \times 2^{\circ}$ grid resolution for a period extended from 1960-2019 [32] to study the influence of IOD and ENSO on enhanced rainfall during October 2019. The IOD Index is computed as the difference in SSTA between the western equatorial IO $\left(50^{\circ} \mathrm{E}-70^{\circ} \mathrm{E}, 10^{\circ} \mathrm{S}-10^{\circ} \mathrm{N}\right)$ and the south-eastern equatorial $\mathrm{IO}\left(90^{\circ} \mathrm{E}-110^{\circ} \mathrm{E}\right.$, $10^{\circ} \mathrm{S}$-Equator) [19]. The mean monthly ENSO indices were computed from the tropical Pacific SST fields at an area bounded with $5^{\circ} \mathrm{S}-5^{\circ} \mathrm{N}, 170^{\circ}-120^{\circ} \mathrm{W}$ (i.e., 
Nino 3.4). These indices stand for the normalized SSTA time series averaged from Niño 3.4. Zonal and meridional winds from the National Centers for Environmental Prediction and the National Center for Atmospheric Research (NCEP-NCAR) re-analysis data [33], were used to study the circulation anomalies associated with enhanced rainfall during positive IOD event. These data sets span with a spatial resolution of $2.5^{\circ} \times 2.5^{\circ}$ grid from 1949 to present.

\subsection{Methods}

The current study employed the singular value decomposition (SVD) to analyze the large scale inter-annual variability between the mean monthly rainfall over the EA and the mean SSTA over the Indian and Pacific Oceans during OND rainfall season with particular interest in 2019 October rainfall variability based on 1981 to 2010 climatology. SVD involves the matrix operation applied to covariance between grid point observations of two fields. It therefore decomposes the matrix of two fields into singular values with two sets of paired-orthogonal vectors namely the loading maps [34]. The SVD analysis in this study explored the leading climatic modes from the mean monthly rainfall over EA and SST over the Indian and Pacific Oceans and their associated principal components (PCs) (i.e. time series of SVD pattern over time), which further ascertained the likely influence of the IOD and ENSO modulation towards enhancing extreme rainfall during October, 2019. Since the PCs provide the strength of SVD pattern over time, the first principal component, which corresponds with the leading mode (i.e., PC1, in Figure 8(c)) was assigned to represent the rainfall indices.

Even though the IOD operates independently of the ENSO but we owe to study the interaction between the two indices towards enhancing rainfall during October 2019 since the proximity between the Indian and Pacific Oceans, and the existence of oceanic and atmospheric pathways, facilitate mutual interactions between these tropical climate modes [30]. Quantifying the likely association between IOD, ENSO and the mean October rainfall over the eastern Africa based on 1981-2010 climatology, we first defined their respective indices and later computed their respective correlation.

The ENSO index was computed by averaging the normalized SST from Niño 3.4 region $\left(5^{\circ} \mathrm{S}-5^{\circ} \mathrm{N}, 170^{\circ}-120^{\circ} \mathrm{W}\right)$, while the IOD is expressed in terms of dipole mode index (DMI), which defines the difference in SSTA between the western equatorial IO $\left(50^{\circ} \mathrm{E}-70^{\circ} \mathrm{E}, 10^{\circ} \mathrm{S}-10^{\circ} \mathrm{N}\right)$ and the south-eastern equatorial IO $\left(90^{\circ} \mathrm{E}-110^{\circ} \mathrm{E}, 10^{\circ} \mathrm{S}\right.$-Equator). Revealing the circulation anomalies responsible for the enhanced rainfall during October 2019, the present study computed anomaly (i.e., the departure from the mean) fields for winds and SST. The nonparametric test, Mann-Kendall trend [35] [36] was also used to detect the trend in time series for the mean October rainfall over the bimodal areas of Tanzania and EA in general and tested for the corresponding significance at $95 \%$ confidence interval. Noted that, all the anomalies were calculated with respect to 1981-2010 climatology. 


\section{Results and Discussion}

\subsection{Validation of Gridded Data (GPCC and CHIRPS) to Characterize Rainfall Variability over East Africa}

GPCC and CHIRPS data sets were validated against observed rain gauge data. This was achieved by comparing the GPCC and CHIRPS data and observed station data over Tanzania. The process was meant to identify a better dataset among the two in reproducing the annual rainfall over EA, to be used instead of observed data that is generally short and incomplete. In this case the GPCC and CHIRPS rainfall data sets were extracted as an areal average from Tanzania domain (i.e., $12^{\circ} \mathrm{S}-1^{\circ} \mathrm{S}$ and $30^{\circ} \mathrm{E}-40^{\circ} \mathrm{E}$ ) and compared to the country average of observed station data sets. The results indicate that both GPCC and CHIRPS data sets are in agreement with the observed rainfall data sets, and the pattern from all data sets recapture the two rainfall peaks during MAM and OND seasons (Figure 2) and are consistent with the earlier findings [37] [38]. However, the pattern from August to December (i.e., including the period under study, October-December) shows that both GPCC and CHIRPS gridded data sets are more closely related with the observed data. The correlation coefficient between CHIRPS and observed rainfall data is nearly equivalent to that of GPCC and observed rainfall $(r=0.8194$ and 0.8184$)$ respectively. From these statistics, it is clear that both datasets are good in representing observed rainfall over EA. Thus they can be used to characterize rainfall over EA. However, CHIRPS rainfall data was chosen for further analysis to understand the long-term rainfall variability over EA due to its advantage of using the blend of rain gauge and Satellite data.

Generally, the monthly rainfall climatology indicates that, during October the region (i.e., mainly Tanzania and Kenya) receives less amount of rainfall (less than $50 \mathrm{~mm}$ ) while the highest rainfall record between $100 \mathrm{~mm}$ and $250 \mathrm{~mm}$ is

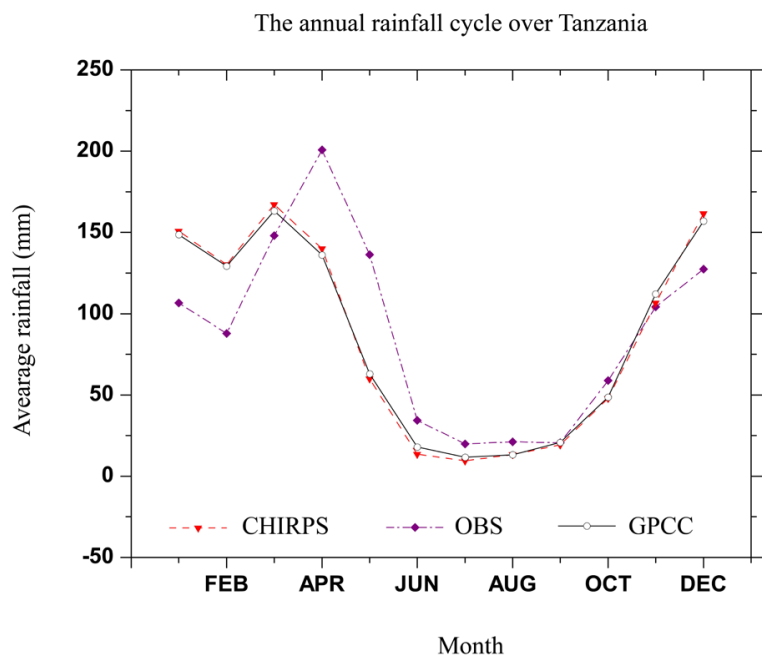

Figure 2. The annual cycle of Tanzania rainfall $\left(\mathrm{mm} \mathrm{day}^{-1}\right)$ computed as the areal-average of the country (i.e., $12^{\circ} \mathrm{S}-1^{\circ} \mathrm{S}$ and $30^{\circ} \mathrm{E}-40^{\circ} \mathrm{E}$ ) from GPCC (black solid circled line), CHIRPS (red dashed line with triangles) and observed rain-gauge data sets (purple dash-dot line) based on 1981 to 2010 climatology. 
observed over the larger domain of Uganda and a small area over the central Kenya (Figure 3). The coastal strip of Kenya and Tanzania (mainly the northern coast), areas to the north-west of Tanzania (i.e., around Lake Tanganyika and Lake Victoria basin (LVB)) only receive a considerable amount of rainfall (between $50 \mathrm{~mm}$ and $150 \mathrm{~mm}$ ) compared to other areas in Kenya and Tanzania. This is in agreement with the expected rainfall pattern since these areas benefit from the moisture influx from the Lakes and the IO [39]. It is almost wet all over the region with an exception of some areas over the north-west Kenya and central Tanzania during November (Figure 3). The higher amount of rainfall between $100 \mathrm{~mm}$ and $250 \mathrm{~mm}$ is mainly observed over northwestern Tanzania, Most of Uganda and southern parts of Kenya extending to the coastline of northern Tanzania. The observed scenario is consistent with the earlier finding by [11] that during OND season, rainfall over the EA region peaks in November. In December the majority of the areas in Tanzania (Figure 3) receive enhanced amount of rainfall (between $150 \mathrm{~mm}$ and $250 \mathrm{~mm}$ ) over the western, South Western Highlands (SWH) extending to southern region of Tanzania while less
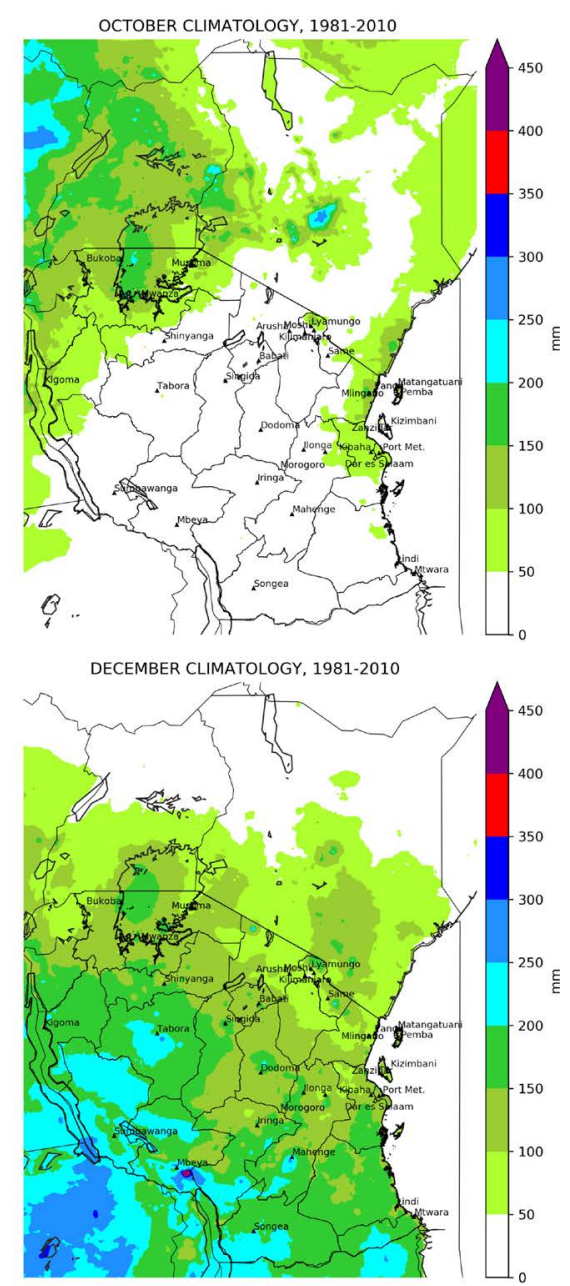

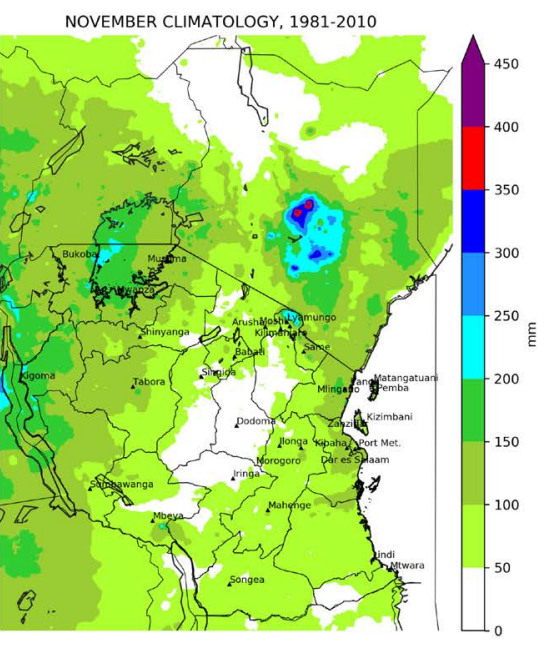

OND CLIMATOLOGY 1981-2010

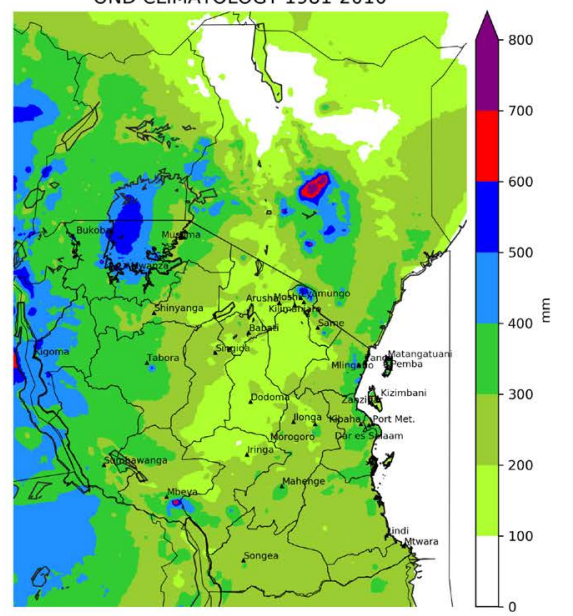

Figure 3. The mean monthly (October, November December) and seasonal (October-December) rainfall distribution based on CHIRPS 1981-2010 climatology. 
amount of rainfall in the range between $50 \mathrm{~mm}$ and $150 \mathrm{~mm}$ are observed over the northern part of Tanzania and southern parts of Kenya and Uganda. (Figure 3), this is due to the fact that the ITCZ is far south [40]. The rainfall distribution in OND (Figure 3 ) shows that the western sector of Tanzania, areas around the LVB, the large area of Uganda, central Kenya and the coastal belt of Kenya and Tanzania record high amounts of rainfall between $300 \mathrm{~mm}$ and $650 \mathrm{~mm}$.

The present study investigated the variability of the 2019 OND rainfall pattern over EA region and revealed a noticeable significant change in its distribution especially during October (Figure 4). The results reveal that most parts of the EA region recorded above normal rainfall, while areas around Lake Victoria Basin, central Kenya and the coastal strip of Kenya and Tanzania received the highest rainfall amounts exceeding their respective long-term mean by between $100 \mathrm{~mm}$ and $450 \mathrm{~mm}$. Most of the meteorological stations in Tanzania recorded well above normal rainfall, with stations such as Arusha, Moshi, Babati, Same and Kilimanjaro over the North-eastern highland Tanzania, and Pemba, Ilonga and Morogoro over the northern coast recording between $500 \%$ to $1100 \%$ of their long-term mean (Figure 5).

To investigate further the temporal distribution of the October rainfall pattern over the EA, the inter-annual variability of IOD index and the October rainfall over the bimodal areas of Tanzania is shown in Figure 6. The highest frequency of the October rainfall over the entire climatology (Figure 6) is observed in 2019. The observation of the October 2019 rainfall anomaly in Figure 6 records the highest in history compared to the rest of the years (e.g., 1982 and 1997) where both the warm phase of ENSO and positive IOD coincided [41] [42].

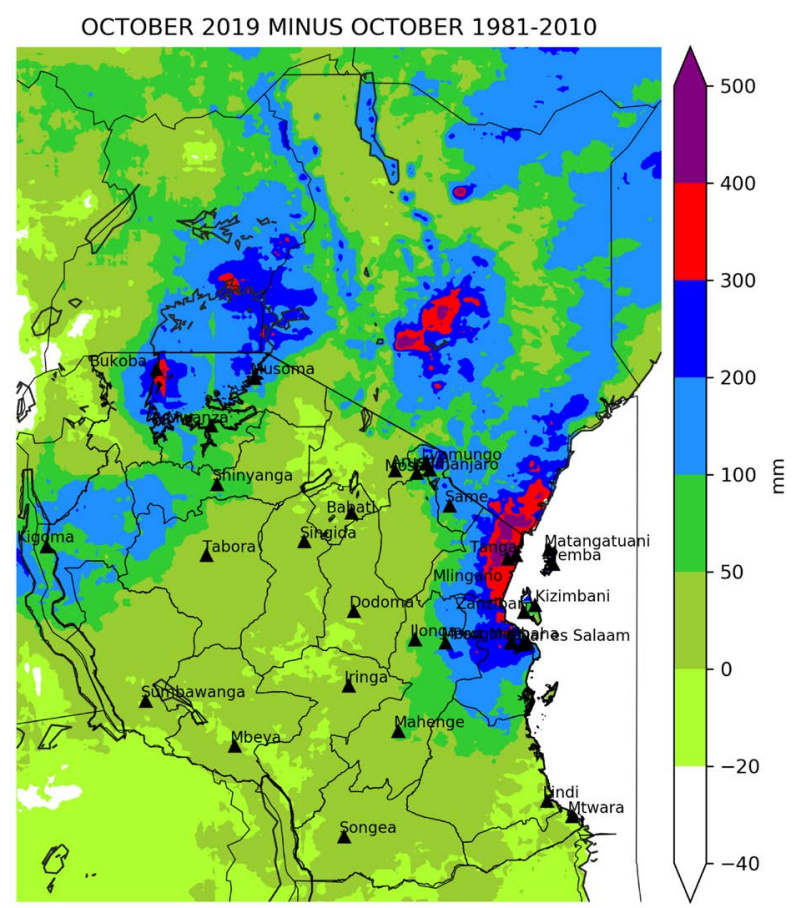

Figure 4. The mean October, 2019 rainfall anomaly $(\mathrm{mm})$ based on 1981-2010 climatology. 


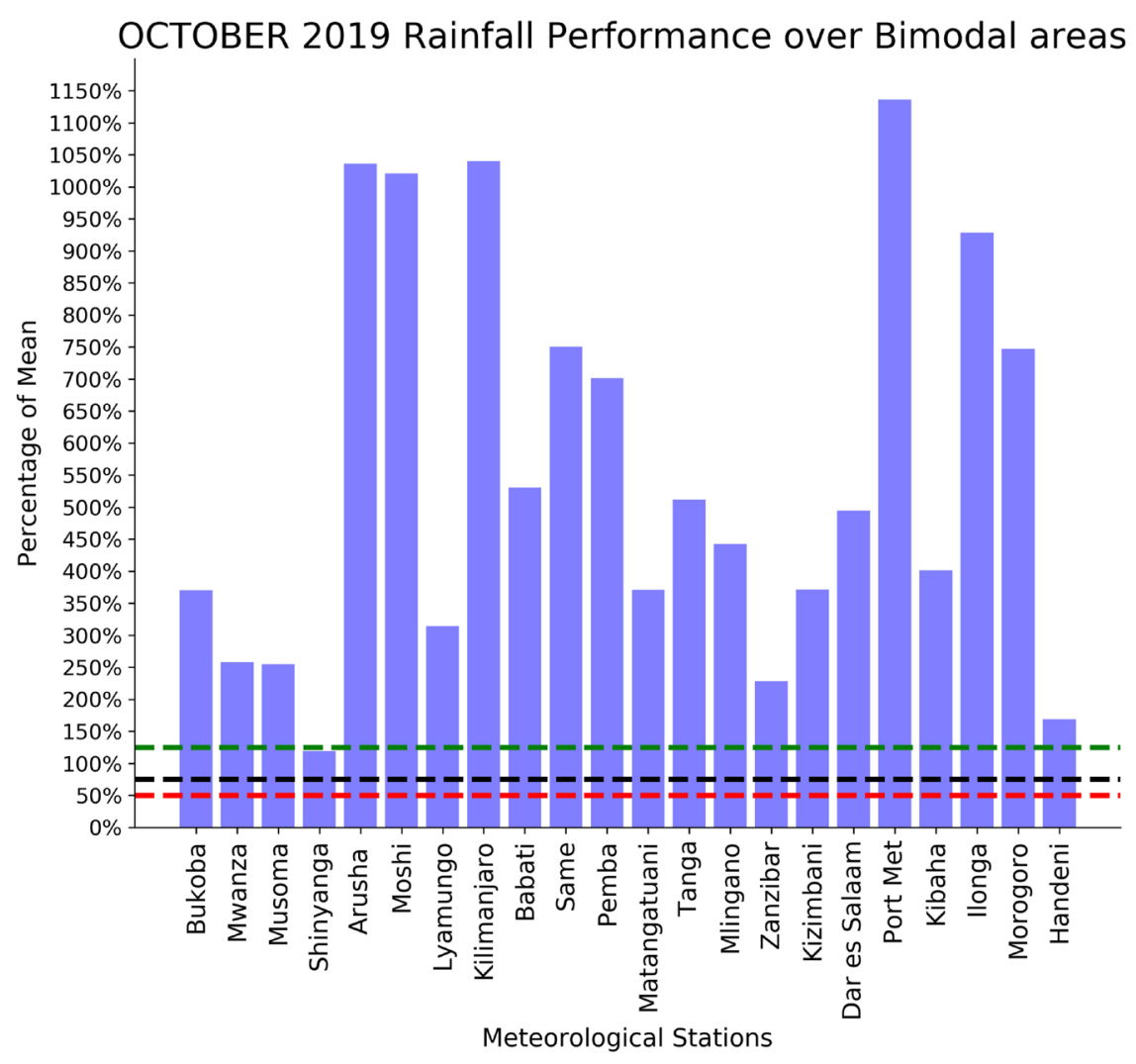

Figure 5. The percentage of the October, 2019 rainfall from the long-term mean (1981-2010).

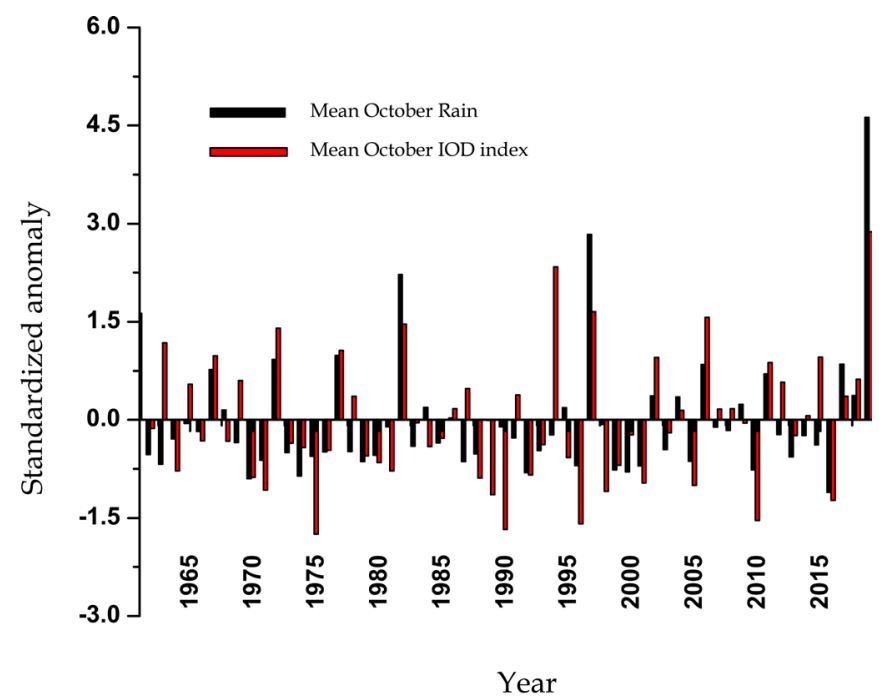

Figure 6. The 1961-2019 inter-annual variability of IOD index (red bars) and the October rainfall (black bars) over the bimodal areas of Tanzania.

Interestingly, even though a detailed discussion on the physical features associated with the October 2019 anomalous rainfall will be given later in this study, but a close linkage between the SST variability over the IO and the October rainfall anomalies is clearly noted (Figure 6). Thus, the enhanced (suppressed) 
rainfall anomalies during October are found to be associated with positive (negative) phase of the IOD index and the 2019 positive October rainfall anomaly recorded the highest positive phase IOD event in history.

The MK-trend test in Figure 7 is carried out aiming at verifying the temporal distribution of the October rainfall pattern. The sequential MK-trend test in the present study graphically illustrates the forward, $\mathrm{u}(\mathrm{F})$ and backward, $\mathrm{u}(\mathrm{B})$ trends of the October rainfall over the EA domain and the bimodal areas in Tanzania (Figure 7). It is revealed that, when a set of two series, a forward and backward one cross each other and diverge beyond the specific threshold value (i.e. at $95 \%$ confidence interval for the current study), then the point is said to be significant change point.

A typical sequential MK-trend test for the October rainfall over the bimodal areas of Tanzania (Figure 7(a)) shows that, generally, the region is in favor of increasing trend with abrupt changes marked from 1982 to 2019 window. However, both the trend and the changing points are insignificant at $95 \%$ confidence interval. Figure 7(a) indicates that the October rainfall trend started with a decreasing trend from 1982 until 2000-2001 where a significant decrease in trend noted and thereafter learned towards increasing trend. Over the eastern Africa (Figure 7(b)), the October rainfall pattern shows an increasing trend with abruptly changes observed from 2008 to 2016 . Likewise, the progressive series, $u$ (F) for both the rainfall trend and changing points over the EA domain are not above the critical limit suggesting the fact that are not significant at $95 \%$ confidence interval.

\subsection{Circulation Anomalies Associated with Extreme Rainfall during October 2019}

The likely cause for the enhanced rainfall anomaly during October and its possible linkage to SST were analyzed using the SVD, correlation and composite analysis methods. The results in Table 1 give a summary of the statistics for the first two leading modes in SVD expansion between the mean October rainfall

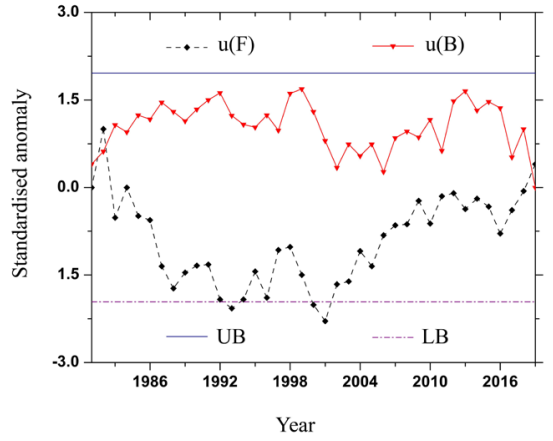

(a)

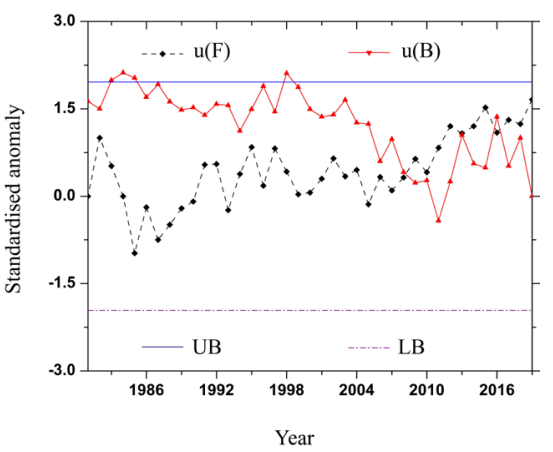

(b)

Figure 7. Sequential Mann-Kendall tests of October rainfall over (a) the bimodal area in Tanzania (b) East Africa region. Dotted (brown color) and solid (blue color) horizontal lines indicate critical values corresponding to 95\% confidence interval. (a) MK trend (Oct rainfall), Tanzania; (b) MK trend (Oct rainfall), East Africa. 
Table 1. The squared covariance for the first two leading modes of a direct SVD expansion expressed in percentage and the temporal correlation coefficient between the expansion coefficients of the mean rainfall and SST anomalies, $r$ (rain, SSTA) over the Indian and Pacific Oceans during October of 1981 to 2010.

\begin{tabular}{ccccc}
\hline Mode & SCF (\%) & r (rain, SSTA) & rain Variance (\%) & SST Variance (\%) \\
\hline 1 & 75.21 & 0.7837 & 24.7 & 36.6 \\
2 & 10.21 & 0.6860 & 9.27 & 17.29 \\
\hline
\end{tabular}

and SST anomalies over the Indian and Pacific Oceans. The squared covariance fraction (SCF) results in Table 1 strongly concentrate in the first two modes and account for about $85.42 \%$ of the total squared covariance. Notably, from the first mode the fractions of the variances corresponding to rainfall and SSTA field time series for the expansion coefficient component are $24.7 \%$ and $36.6 \%$ respectively. Generally, the expansion coefficients for both modes as indicators in strength of coupling, exhibit correlation coefficients of greater than 0.5 (see Table 1). The statistics indicated in Table 1 clearly signify how important the first two modes are in explaining the association between EA October rainfall and SST anomalies variability over the Indian and Pacific Oceans.

The first SVD (i.e., SVD1) coupled modes (in Figure 8(a) and Figure 8(b)) which dominate the co-variability between the October rainfall over the EA region and SSTA over the Indian and Pacific Oceans, shows a monopole positive co-variability with rainfall over the entire EA domain (Figure 8(a)). However, the corresponding spatial pattern for the SSTA in Figure 8(b) clearly indicate the establishment of the dipole like pattern over the IO with positive loadings to the western tropical Indian Ocean (WTIO) and negative to the eastern tropical India Ocean (ETIO) near Sumatra and Java. The scenario recaptures the positive phase of IOD as noted earlier by a number of researchers [41] [42] [43]. Likewise, the central equatorial Pacific Ocean (i.e., over Niño 3.4 region in Figure 8 (b)) reveals a monopole positive loading clearly signifying the warm phase of ENSO signals [45]. It is therefore noted that, positive rainfall anomalies in EA during October are associated with increasing SST over the central and eastern equatorial Pacific, a typical warm phase of ENSO phenomenon. Furthermore, positive October rains anomalies are associated with a clear SST gradient in the IO (i.e., increasing SST to the west and decreasing to the east), which is a typical positive IOD event.

Furthermore, assessing the coupling strength of the association between the October rainfall over the eastern Africa and the different phases of IOD and ENSO, the current study computes the correlation with their respective indices. The calculation of the IOD index follows the definition by [44], that is the difference between the SSTA in the western $\left(10^{\circ} \mathrm{S}-10^{\circ} \mathrm{N} ; 50^{\circ}-70^{\circ} \mathrm{E}\right)$ and the eastern $\left(10^{\circ} \mathrm{S}\right.$-Equator; $\left.90^{\circ}-110^{\circ} \mathrm{E}\right)$ tropical IO. On the other hand, the ENSO index is the SSTA averaged over the "Niño $3.4^{\prime}$ " region $\left(5^{\circ} \mathrm{S}-5^{\circ} \mathrm{N} ; 120^{\circ}-170^{\circ} \mathrm{W}\right)$ of the equatorial Pacific. The rainfall index was computed based on PC1 time series for the October rainfall over the EA as indicated in Figure 8(c). It should be noted 


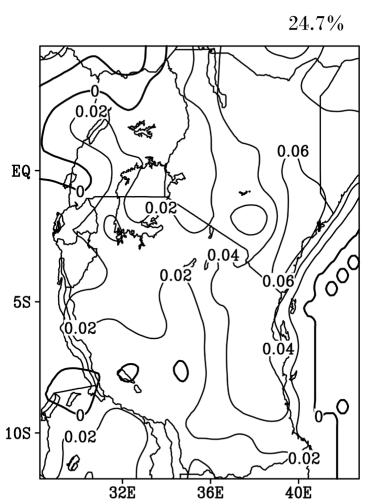

(a)

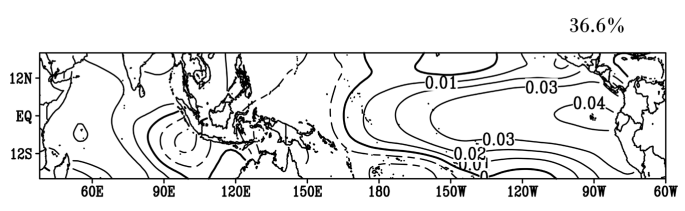

(b)

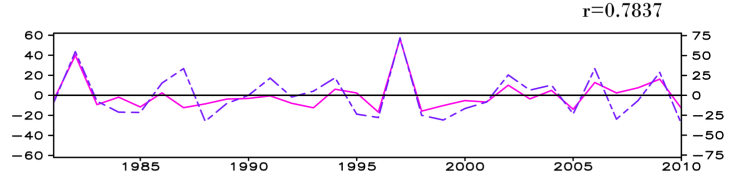

(c)

Figure 8. The loading maps for the first SVD modes during (a) October rainfall anomaly (b) sea surface temperature over the Indian Ocean, Pacific Ocean and the corresponding principal component time series based on 1981-2010 (c). The fractions of variance of the normalized data field explained by the respective modes are indicated in the right-hand corner of each map. (a) SVD1 (Rain); (b) Model; (c) PC1.

that, all the indices above are divided by their respective standard deviation for comparison's sake based on the 1981-2010 climatology.

Figure 9 displays the inter-annual variability between October rainfall over the EA, IOD and ENSO indices. There is a moderate inter-annual fluctuation between the October rainfall and ENSO index (i.e., $r=0.4212$ in Figure 9(a)) while a strong fluctuation is revealed with the IOD index (i.e., $r=0.7084$ in Figure $9(\mathrm{~b})$ ). With some specific years, all the three indices seem to be in phase and strong positive (i.e., 1982, 1997 and 2006), which suggest the fact that positive IOD event usually, coincides with El Niño and becomes much stronger as the intensity of El Niño increases [46]. Exceptionally, some years (i.e., 2011 and 2019 in Figure 9) the IOD and rainfall indices noted to be out of phase with the ENSO index and even substantially higher in magnitude. In particular, the year 2019 (Figure 9(b)) shows that the October rainfall over the EA and IOD indices are strongly higher and independent with the ENSO event. At this stage, it reveals the fact that the IOD coupled mode (particularly the positive phase of IOD) remained the dominant mode controlling the October rainfall variability over the EA region in expenses of the ENSO condition. Understanding the unique feature of the IOD event associated with the enhanced rainfall during October 2019, the present study analyses and compare the SSTA and wind patterns to that of October 1997 which peaked the second in rainfall record (Figure 6) based on 1961 to 2019 climatology.

Figure 9 displays the inter-annual variability between October rainfall over the EA, IOD and ENSO indices. There is a moderate inter-annual fluctuation between the October rainfall and ENSO index (i.e., $r=0.4212$ in Figure 9(a)) while a strong fluctuation is revealed with the IOD index (i.e., $r=0.7084$ in Figure 9(b)). With some specific years, all the three indices seem to be in phase and strong positive (i.e., 1982, 1997 and 2006), which suggest the fact that positive IOD event usually, coincides with El Niño and becomes much stronger as the 


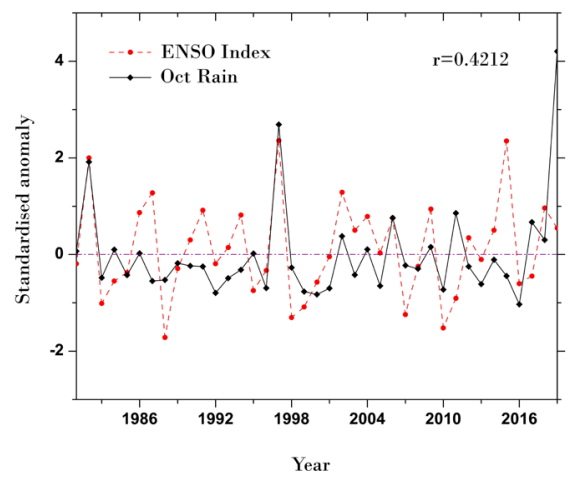

(a)

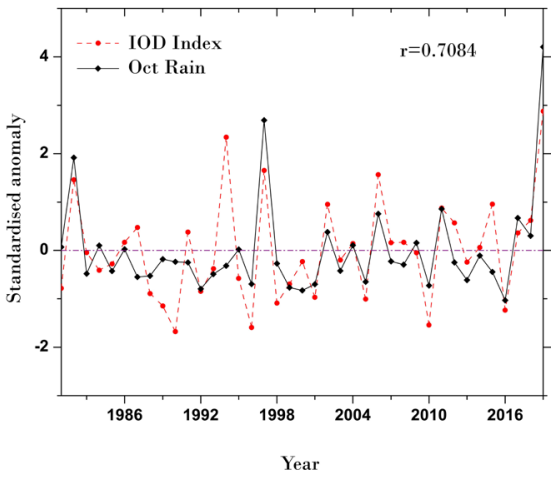

(b)

Figure 9. The inter-annual variability between the October rainfall field over the EA region and (a) ENSO index (b) IOD index based on 1981-2019 climatology. (a) Inter-annual variability (ENSO and Oct Rains); (b) Inter-annual variability (IOD and Oct Rains).

intensity of El Niño increases [46]. Exceptionally, some years (i.e., 2011 and 2019 in Figure 9) the IOD and rainfall indices noted to be out of phase with the ENSO index and even substantially higher in magnitude. In particular, the year 2019 (Figure 9(b)) shows that the October rainfall over the EA and IOD indices are strongly higher and independent with the ENSO event. At this stage, it reveals the fact that the IOD coupled mode (particularly the positive phase of IOD) remained the dominant mode controlling the October rainfall variability over the EA region in expenses of the ENSO condition. Understanding the unique feature of the IOD event associated with the enhanced rainfall during October 2019, the present study analyses and compare the SSTA and wind patterns to that of October 1997 which peaked the second in rainfall record (Figure 6) based on 1961 to 2019 climatology.

During October 1997, the SSTA fields over the Pacific Ocean shows that, the El Niño event is characterized by high SSTA over the central and eastern tropical sector while low SSTA to the western sector (Figure 10(a)). The condition recaptures the warm phase ENSO condition and thus likely to be the cause of enhanced October rainfall anomaly over the EA. On the other hand, a remarkable feature of the dipole mode condition with warm SSTA to the western and cool SSTA to the eastern tropical IO is observed (Figure 10(a)) over the IO recapturing the positive phase of the IOD mode. Meanwhile the warm phase of ENSO and positive IOD event depicted in Figure 10(a) coupled the strengthened easterly wind anomaly (Figure 11(a)) along the Equatorial IO, which decelerate as it approaches the coastal belt of the EA region. It is noted that in October 1997, the enhanced rainfall anomaly was firmly associated with the in-phase influence from the positive phase of IOD event and the warm phase of ENSO. During October 2019 (Figure 10(b)) the Pacific Ocean was mostly characterized by relatively weak or slightly warmer SSTA over the central and eastern tropical sector (i.e., over Niño 3.4 region). The scenario recaptures the neutral ENSO condition with less influence to the October rainfall pattern over the EA region. However, 


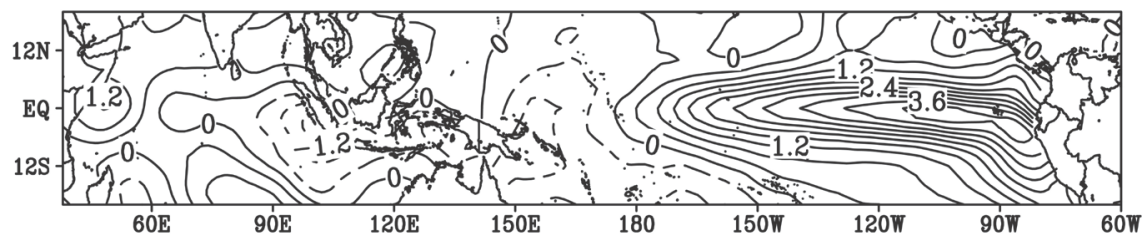

(a)

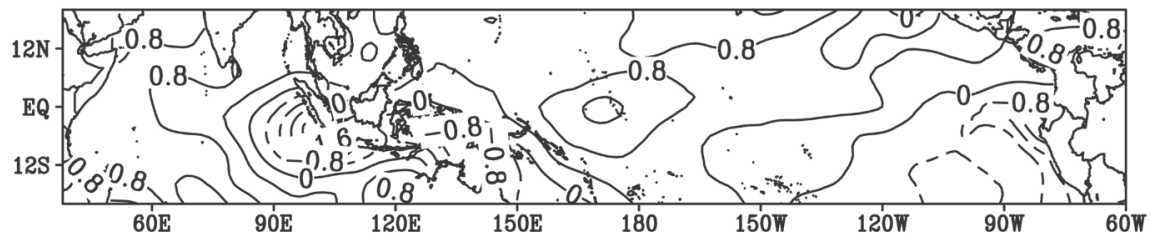

(b)

Figure 10. The sea surface temperature anomaly $\left({ }^{\circ} \mathrm{C}\right)$ during October for the year (a) 1997 and (b) 2019 based on 1981-2010 climatology. (a) Sea surface temperature, Oct 1997; (b) Sea surface temperature, Oct 2019.

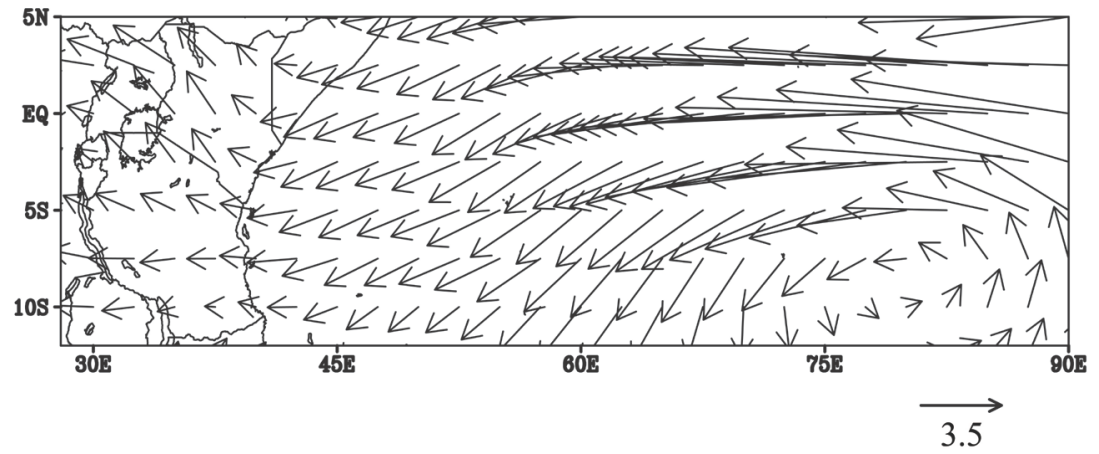

(a)

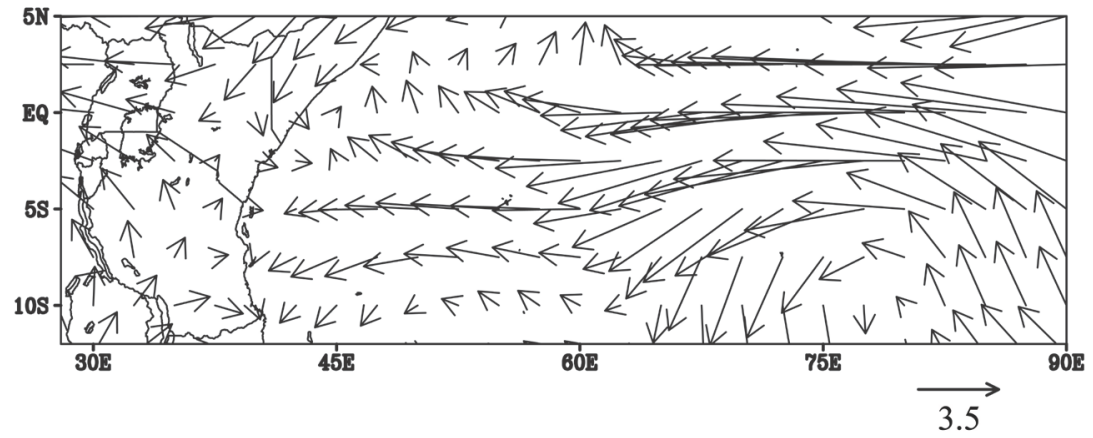

(b)

Figure 11. The anomaly distribution field for the $850 \mathrm{hPa}$ wind $\left(\mathrm{m} \cdot \mathrm{s}^{-1}\right)$ during October for the year (a) 1997 and (b) 2019 based on 1981-2010 climatology. (a) 850 UV hPa, Oct 1997; (b) 850 UV hPa, Oct 2019.

the conditions over the IO (Figure 10(b)) reveal the positive SSTA to the western while negative SSTA to the eastern tropical IO. The scenario recaptures the positive IOD event with strong easterlies anomalies along the equatorial IO decelerating and converges with the southwesterly wind (i.e., moisten wind sourced from Congo basin) along the EA coastal belt. Notably, the anomalous 
rainfall recorded in October 2019 was influenced by the strong positive IOD event (Figure 6, Figure 9(b) and Figure 10(b)) opposite to the dual influence (i.e., in phase condition of the IOD and ENSO) revealed during October 1997. While the IOD operates independently of the ENSO, the proximity between the Indian and Pacific Oceans, and the existence of oceanic and atmospheric pathways, still facilitate mutual interactions between these tropical climate modes [46].

\subsection{Socio-Economic Impacts of the Extreme Rainfall in October 2019}

The socio-economic impacts of extreme rainfall events in October 2019 were widespread and consequential ranging from loss of life and properties, to severe destruction of infrastructure including destruction of houses, roads, bridges, crop farms, and displacement of people. More than 32 people were reported dead as a result of the flooding in Tanzania. A detailed description of the extreme rainfall events and the associated impacts for Tanzania is provided in $\mathrm{Ta}$ ble 2, and it provide description of the meteorological stations, which set new records of the highest 24 hours rainfall since the establishment of the station. This observation is consistent with the findings from the IPCC special report on global warming of $1.5^{\circ} \mathrm{C}$, which indicates an increase in frequency and intensity of heavy precipitation in many regions [22] [23] [24].

Report from Kenya Red Cross (KRC) confirmed that, in early October 2019 flooding events associated with heavy rains had resulted in riverine, rock falls,

Table 2. Extreme rainfall events and their associated impacts in October 2019.

\begin{tabular}{|c|c|c|c|c|}
\hline Event Dates & $\begin{array}{l}\text { Station name and } \\
\text { Establishment } \\
\text { Year and Location }\end{array}$ & $\begin{array}{l}24 \text { hours } \\
\text { Rainfall amount } \\
\quad(\mathrm{mm})\end{array}$ & Rank of the Event & Impacts \\
\hline 09/10/2019 & $\begin{array}{l}\text { Korogwe Maji } \\
\quad(1961) \\
\text { Latitude: } 5^{\circ} 9^{\prime} \\
\text { Longitude: } 38^{\circ} 28^{\prime} \\
\text { Elevation: } 259 \mathrm{~m}\end{array}$ & $175.9 \mathrm{~mm}$ & $\begin{array}{l}\text { Highest } 24 \text { hours } \\
\text { Rainfall for October, } \\
\text { and third highest } \\
\text { record for all months }\end{array}$ & $\begin{array}{l}7 \text { deaths reported in Bungu, Dindira and } \\
\text { Vungo villages in Korogwe District } \\
\text { Over } 300 \text { families were left homeless after } \\
\text { their houses were severely destroyed } \\
\text { (Mwananchi Newspaper, 10th October 2019) }\end{array}$ \\
\hline $13 / 10 / 2019$ & $\begin{array}{l}\text { Tanga (1941) } \\
\text { Latitude: } 5^{\circ} 5^{\prime} \\
\text { Longitude: } 39^{\circ} 4^{\prime} \\
\text { Elevation: } 49 \mathrm{~m}\end{array}$ & $102.3 \mathrm{~mm}$ & $\begin{array}{l}\text { Sixth highest } 24 \text { hours } \\
\text { Rainfall for October }\end{array}$ & $\begin{array}{l}\text { The Dar es Salaam to Tanga road was } \\
\text { impassable causing transport disruption } \\
\text { (HabariLeo, 14th October 2019) }\end{array}$ \\
\hline $24 / 10 / 2019$ & $\begin{array}{l}\text { Handeni }(1928) \\
\text { Latitude: } 5^{\circ} 26^{\prime} \\
\text { Longitude: } 38^{\circ} 2^{\prime} \\
\text { Elevation: } 756 \mathrm{~m}\end{array}$ & $123.7 \mathrm{~mm}$ & $\begin{array}{l}\text { Highest } 24 \text { hours } \\
\text { Rainfall for October }\end{array}$ & $\begin{array}{c}14 \text { people died in Handeni district } \\
\text { (European Civil Protection and Humanitarian } \\
\text { Aid Operation }(E C H O), 28 \text { th October 2019). } \\
15 \text { bridges were damaged, and about } 40 \text { houses } \\
\text { collapsed and other } 70 \text { houses drowned, } \\
\text { Flooded and destroyed bridges leading to disrupted } \\
\text { transport between Dar es Salaam and Arusha } \\
\text { (Daily News, } 27^{\text {th }} \text { October 2019) }\end{array}$ \\
\hline $11 / 10 / 2019$ & $\begin{array}{l}\text { Morogoro }(1950) \\
\text { Latitude: } 6^{\circ} 50^{\prime} \\
\text { Longitude: } 37^{\circ} 39^{\prime} \\
\text { Elevation: } 526\end{array}$ & $64.2 \mathrm{~mm}$ & $\begin{array}{l}\text { Highest } 24 \text { hours } \\
\text { Rainfall for October }\end{array}$ & $\begin{array}{c}11 \text { people died due to floods, Farms and food crops } \\
\text { destroyed (European Civil Protection and } \\
\text { Humanitarian Aid Operation (ECHO), } \\
\text { 16th October 2019) }\end{array}$ \\
\hline
\end{tabular}


mudslides and landslides. More than 101,000 people were affected mainly in the north-eastern, central and coastal region of Kenya with at least 29 flood related death toll.

\section{Conclusions and Recommendation}

The temporal and spatial variability of the October 2019 rainfall pattern over the EA region was quite unique over most parts of the region. The spatial variability revealed that the western and northern (over Uganda) LVB, central Kenya and the coastal strip of Kenya and Tanzania received the highest rainfall amount on record in comparison to their respective long-term average. Majority of the stations over the southern and western LVB (i.e., Bukoba, Mwanza and Shinyanga) and northern coast of Tanzania (i.e., Pemba, Dar es Salaam, Dar es Salaam Port and Kibaha) recorded above normal rainfall in comparison to their respective long-term average. Meanwhile, the temporal distribution shows that the October 2019 rainfall anomaly is the highest in history and found to have a close linkage with the positive phase of the Indian Ocean Dipole. Analyzing the rainfall trends, it was found that the October rainfall pattern over the eastern Africa showed an increasing trend with abrupt changes observed from 2008 to 2016. However, the trend was found to be insignificant at $95 \%$ confidence interval.

The SVD1 coupled modes that dominate the co-variability between the October rainfall over the EA region and SSTA over the Indian and Pacific Oceans, indicate the monopole positive co-variability with rainfall over the entire EA domain. On the other hand, the corresponding spatial patterns for the SSTA clearly indicate the establishment of the positive phase of IOD event. Likewise, the central equatorial Pacific Ocean (i.e., over Niño 3.4 region) reveals a monopole positive loading clearly signifying the warm phase of ENSO signals. It is therefore noted that, positive rainfall anomalies in EA during October are associated with increasing SST over the central and eastern equatorial Pacific, a typical warm phase of ENSO phenomenon. Furthermore, enhanced rainfall anomaly during October is found to be associated with SST gradient in the IO (i.e., increasing SST to the west and decreasing to the east), a typical positive IOD event. Assessing the strength of variability between October rainfall over EA and either of the two indices (i.e., ENSO and/or IOD event), a moderate inter-annual fluctuation was revealed with ENSO index (i.e., $\mathrm{r}=0.4212$ ) while a strong fluctuation was observed with the IOD index (i.e., $r=0.7084$ ). To further understand the uniqueness of the October 2019 rainfall pattern it was revealed that, the October rainfall over the EA and IOD indices was strongly higher and independent with the ENSO event. Thus, the positive IOD coupled mode has large impact on the interannual variability controlling the October rainfall variability over the EA region in expenses of the ENSO condition.

\section{Acknowledgements}

The authors wish to express their sincere thanks to the Director General of Tan- 
zania Meteorological Authority and the NCEP/NCAR for making the daily rainfall data sets and reanalysis data available. We also thank the reviewers for their constructive comments, which have helped to improve the quality of the paper.

\section{Conflicts of Interest}

The authors declare no conflicts of interest regarding the publication of this paper.

\section{References}

[1] Kipkogei, O., et al. (2017) Improved Seasonal Prediction of Rainfall over East Africa for Application in Agriculture: Statistical Downscaling of CFSv2 and GFDL-FLOR. Journal of Applied Meteorology and Climatology, 56, 3229-3243. https://doi.org/10.1175/JAMC-D-16-0365.1

[2] Li, C., Li, C., Chai, Y., Yang, L. and Li, H. (2016) Spatio-Temporal Distribution of Flood Disasters and Analysis of Influencing Factors in Africa. Natural Hazards, 82, 721-731. https://doi.org/10.1007/s11069-016-2181-8

[3] Indeje, M., Semazzi, F.H.M. and Ogallo, L.J. (2000) ENSO Signals in East African Rainfall Seasons. International Journal of Climatology, 20, 19-46. https://doi.org/10.1002/(SICI)1097-0088(200001)20:1<19::AID-JOC449>3.0.CO;2-0

[4] Mafuru Biseke, K. and Tan, G. (2019) The Influence of ENSO on the Upper Warm Temperature Anomaly Formation Associated with the March-May Heavy Rainfall Events in Tanzania. International Journal of Climatology, 40, 2745-2763.

[5] Chang'a, L., Yanda, P. and Ngana, J. (2010) Indigenous Knowledge in Seasonal Rainfall Prediction in Tanzania: A Case of the South-Western Highland of Tanzania Climate Variability and Its Impacts in Tanzania View Project. Journal of Geography and Regional Planning, 3, 66-72. http://www.academicjournals.org/JGRP

[6] Chang'a, L.B., Kijazi, A.L., Luhunga, P.M., Ng'ongolo, H.K. and Mtongori, H.I. (2017) Spatial and Temporal Analysis of Rainfall and Temperature Extreme Indices in Tanzania. Journal of Atmospheric and Climate Sciences, 7, 525-539. https://doi.org/10.4236/acs.2017.74038

[7] Chang'a, L.B., Yanda, P.Z. and Ngana, J. (2010) Spatial and Temporal Analysis of Recent Climatological Data in Tanzania. Journal of Geography and Regional Planning, 3, 44-65.

[8] Nsubuga, F.N.W., Olwoch, J.M., de Rautenbach, C.J.W. and Botai, O.J. (2014) Analysis of Mid-Twentieth Century Rainfall Trends and Variability over Southwestern Uganda. Theoretical and Applied Climatology, 115, 53-71. https://doi.org/10.1007/s00704-013-0864-6

[9] Ogallo, L. (1979) Rainfall Variability in Africa. Monthly Weather Review, 107, 1133-1139. https://doi.org/10.1175/1520-0493(1979)107<1133:RVIA>2.0.CO;2

[10] Ogallo, L.J. (1989) The Spatial and Temporal Patterns of the East African Seasonal Rainfall Derived from Principal Component Analysis. International Journal of Climatology, 9, 145-167. https://doi.org/10.1002/joc.3370090204

[11] Ogallo, L.J., Janowiak, J.E. and Halpert, M.S. (1988) Teleconnection between Seasonal Rainfall over East Africa and Global Sea Surface Temperature Anomalies. Journal of the Meteorological Society of Japan, 66, 807-821. https://doi.org/10.2151/jmsj1965.66.6_807

[12] Kijazi, A.L. and Reason, C.J.C. (2005) Relationships between Intraseasonal Rainfall 
Variability of Coastal Tanzania and ENSO. Theoretical and Applied Climatology, 82, 153-176. https://doi.org/10.1007/s00704-005-0129-0

[13] Nyenzi, B.S. (1988) Mechanisms of East African Rainfall Variability. Atmospheric Science, 49, 2232.

[14] Hastenrath, S., Nicklis, A. and Greischar, L. (1993) Atmospheric-Hydrospheric Mechanisms of Climate Anomalies in the Western Equatorial Indian Ocean. Journal of Geophysical Research, 98, 20219. https://doi.org/10.1029/93JC02330

[15] Ogwang, B.A., Chen, H., Li, X. and Gao, C. (2014) The Influence of Topography on East African October to December Climate: Sensitivity Experiments with RegCM4. Advances in Meteorology, 2014, Article ID: 143917. https://doi.org/10.1155/2014/143917

[16] Owiti, Z. (2012) East African Rainfall Seasonality Based on Modulated Annual Cycle (MAC). International Journal of the Physical Sciences, 7, 3050-3061. https://doi.org/10.5897/IJPS12.240

[17] Cook, K.H. and Vizy, E.K. (2013) Projected Changes in East African Rainy Seasons. Journal of Climate, 26, 5931-5948. https://doi.org/10.1175/JCLI-D-12-00455.1

[18] Kabanda, T.A. and Jury, M.R. (1999) Inter-Annual Variability of Short Rains over Northern Tanzania. Climate Research, 13, 231-241. https://doi.org/10.3354/cr013231

[19] Mutai, C.C., Ward, M.N. and Colman, A.W. (1998) Towards the Prediction of the East Africa Short Rains Based on Sea-Surface Temperature-Atmosphere Coupling. International Journal of Climatology, 18, 975-997. https://doi.org/10.1002/(SICI)1097-0088(199807)18:9<975::AID-JOC259>3.0.CO;2$\underline{\mathrm{U}}$

[20] Annamalai, H., Xie, S., McCreary, J. and Murtugudde, R. (2005) Impact of Indian Ocean Sea Surface Temperature on Developing El Niño. Journal of Climate, 18, 302-319. https://doi.org/10.1175/JCLI-3268.1

[21] Hastenrath, S., Polzin, D. and Mutai, C. (2007) Diagnosing the 2005 Drought in Equatorial East Africa. Journal of Climate, 20, 4628-4637. https://doi.org/10.1175/JCLI4238.1

[22] IPCC (2019) Summary for Policymakers. In: Portner, H.O., Roberts, D.C., Masson Delmotte, V., Zhai, P., Tignor, M., Poloczanska, E., Mintenbeck, K., Alegria, A., Nicolai, M., Okem, A., Petzold, J., Rama, B. and Weyer, N.M., Eds., IPCC Special Report on the Ocean and Cryosphere in a Changing Climate, Cambridge University Press, Cambridge. (In Press)

[23] IPCC (2019) Summary for Policymakers. In: Shukla, P.R., Skea, J., Calvo Buendia, E., Masson Delmotte, V., Portner, H.O., Roberts, D.C., Zhai, P., Slade, R., Connors, S., van Diemen, R., Ferrart, M., Haughey, E., Luz, S., Neogi, S., Pathak, M., Petzold, J., Portugal Pereira, J., Vyas, P., Huntley, E., Kissick, K., Belkacemi, M. and Malley, J., Eds., Climate Change and Land: An IPCC Special Report on Climate Change, Desertification, Land Degradation, Sustainable Land Management, Food Security, and Greenhouse Gas Fluxes in Terrestrial Ecosystems, Cambridge University Press, Cambridge. (In Press)

[24] IPCC (2018) Summary for Policymakers. In: Masson Delmotte, V., Zhai, P., Portner, H.O., Roberts, D.C., Skea, J., Shukla, P.R., Pirani, A., Mouffouma-Okia, W., Pean, C., Pidcock, R., Connors, S., Matthews, J.B.R., Chen, Y., Zhou, X., Gomis, M.I., Lonnoy, E., Maycock, T., Tignor, M. and Waterfield, T., Eds., Global Warming of $1.50{ }^{\circ} \mathrm{C}$. An IPCC Special Report on the Impacts of Global Warming of $1.50{ }^{\circ} \mathrm{C}$ above Pre-Industrial Levels and Related Global Greenhouse Gas Emission Path- 
ways, in the Context of Strengthening the Global Response to the Threat of Climate Change, Sustainable Development, and Efforts to Eradicate Poverty, World Meteorological Organization, Geneva, $32 \mathrm{p}$.

[25] Izumo, T., Vialard, J., Lengaigne, M., de Boyer, M.C., Behera, S.K., Luo, J.-J., Cravatte, S., Masson, S. and Yamagata, T. (2010) Influence of the State of the Indian Ocean Dipole on the Following Year's El Niño. Nature Geoscience, 3, 168-172.

https://doi.org/10.1038/ngeo760

[26] Latif, M., et al. (1999) The Role of Indian Ocean Sea Surface Temperature in Forcing East African Rainfall Anomalies during December-January 1998. Journal of Climate, 12, 3497-3504. https://doi.org/10.1175/1520-0442(1999)012<3497:TROIOS >2.0.CO;2

[27] Saji, N.H., Goswami, B.N., Vinayachandran, P.N. and Yamagata, T. (1999) A Dipole Mode in the Tropical Indian Ocean. Nature, 401, 360-363. https://doi.org/10.1038/43854

[28] Wallace, J.M., Smith, C. and Bretherton, C.S. (1992) Singular Value Decomposition of Wintertime Sea Surface Temperature and 500-mb Height Anomalies. Journal of Climate, 5, 561-576. https://doi.org/10.1175/1520-0442(1992)005<0561:SVDOWS >2.0.CO;2

[29] Nicholson, S.E. (2017) Climate and Climatic Variability of Rainfall over Eastern Africa. Reviews of Geophysics, 55, 590-635. https://doi.org/10.1002/2016RG000544

[30] Saji, N.H. (2018) The Indian Ocean Dipole, Oxford Research Encyclopedia of Climate Science.

[31] Funk, C., Peterson, P., Landsfeld, M., Pedreros, D., Verdin, J., Shukla, S., Husak, G., Rowland, J., Harrison, L., Hoell, A. and Michaelsen, J. (2015) The Climate Hazards Infrared Precipitation with Stations: A New Environmental Record for Monitoring Extremes. Scientific Data, 2, 1-21. https://doi.org/10.1038/sdata.2015.66

[32] Slingo, J., Spencer, H., Hoskins, B., Berrisford, P. and Black, E. (2005) The Meteorology of the Western Indian Ocean, and the Influence of the East African Highlands. Philosophical Transactions of the Royal Society A: Mathematical, Physical and Engineering Sciences, 363, 25-42. https://doi.org/10.1098/rsta.2004.1473

[33] Kalnay, E., Kanamitsu, M., Kistler, R., Collins, W., Deaven, D., Gandin, L., Iredell, M., Saha, S., White, G., Woollen, J., Zhu, Y., Chelliah, M., Ebisuzaki, W., Higgins, W., Janowiak, J., Mo, K.C., Ropelewski, C., Wang, J., Leetmaa, A. and Reynolds, R. (1996) The NCEP/NCAR 40-Year Reanalysis Project. Bulletin of the American Meteorological Society, 77, 437-471. https://doi.org/10.1175/1520-0477(1996)077<0437:TNYRP>2.0.CO;2

[34] Smith, T.M., Reynolds, R.W., Peterson, T.C. and Lawrimore, J. (2008) Improvements to NOAA's Historical Merged Land-Ocean Surface Temperature Analysis (1880-2006). Journal of Climate, 21, 2283-2296. https://doi.org/10.1175/2007JCLI2100.1

[35] Mann, H.B. (1945) Nonparametric Tests against Trend. Econometrica, 13, 245-259. https://doi.org/10.2307/1907187

[36] Kendall, M.G. (1975) Rank Correlation Methods. Griffin, London.

[37] Camberlin, P. and Okoola, R.E. (2003) The Onset and Cessation of the "Long Rains" in Eastern Africa and Their Interannual Variability. Theoretical and Applied Climatology, 75, 43-54. https://doi.org/10.1007/s00704-002-0721-5

[38] World Meteorological Organization (2019) WMO Statement on the State of Global Climate in 2019. WMO, Geneva.

[39] Mukabana, J.R. and Pielke, R.A. (1996) Investigating the Influence of Synoptic-Scale 
Monsoonal Winds and Mesoscale Circulations on Diurnal Weather Patterns over Kenya Using a Mesoscale Numerical Model. Monthly Weather Review, 124, 224-243. https://doi.org/10.1175/1520-0493(1996)124<0224:ITIOSS >2.0.CO;2

[40] Nicholson, S.E. (1996) A Review of Climate Dynamics and Climate Variability in Eastern Africa. In: Ivan Johnson, A., Ed., Limnology, Climatology and Paleoclimatology of the East African Lakes, CRC Press, Boca Raton, 25. https://doi.org/10.1201/9780203748978-2

[41] Webster, P.A.M., Loschnigg, J.P. and Leben, R.R. (1999) Coupled Ocean-Atmosphere Dynamics in the Indian Ocean during 1997-98. Nature, 401, 356-360. https://doi.org/10.1038/43848

[42] Wenhaji, N.C., Cattani, E., Merino, A. and Levizzani, V. (2018) An Observational Study of the Variability of East African Rainfall with Respect to Sea Surface Temperature and Soil Moisture. Quarterly Journal of the Royal Meteorological Society, 144, 384-404. https://doi.org/10.1002/qj.3255

[43] Goddard, L. and Graham, N.E. (1999) Importance of the Indian Ocean for Simulating Rainfall Anomalies over Eastern and Southern Africa. Journal of Geophysical Research, 104, 19099-19116. https://doi.org/10.1029/1999JD900326

[44] Parhi, P., Giannini, A., Gentine, P. and Lall, U. (2016) Resolving Contrasting Regional Rainfall Responses to EL Niño over Tropical Africa. Journal of Climate, 29, 1461-1476. https://doi.org/10.1175/JCLI-D-15-0071.1

[45] Negrón Juárez, R.I., Robinson, I., Li, W., Fernandes, K. and de Oliveira Cardoso, A. (2009) Comparison of Precipitation Data Sets over the Tropical South American and African Continents. Journal of Hydrometeorology, 10, 289-299. https://doi.org/10.1175/2008JHM1023.1

[46] Trenberth, K.E. and Hoar, T.J. (1997) El Niño and Climate Change. Geophysical Research Letters, 24, 3057-3060. 